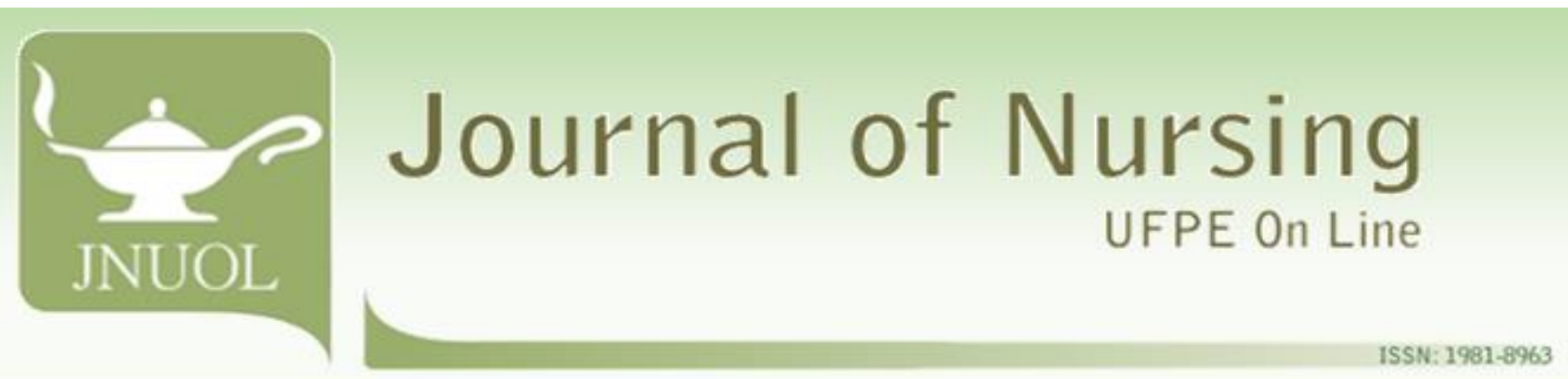

\title{
INTEGRATIVE REVIEW ARTICLE
}

\section{NURSING CARE FOR ELDERLY PATIENTS WITH DELIRIUM IN INTENSIVE CARE UNITS CUIDADO DE ENFERMAGEM AO IDOSO COM DELIRIUM EM UNIDADE INTENSIVA CUIDADO DE ENFERMERÍA AL ADULTO MAYOR COM DELIRIUM EN UNIDAD INTENSIVA}

Larissa Simões da Cruz Pessoa ${ }^{1}$, Tânia Maria de Oliva Menezes ${ }^{2}$, Nildete Pereira Gomes ${ }^{3}$, Gildasio Souza Pereira ${ }^{4}$, Verônica Matos Batista ${ }^{5}$, Liliam Macedo Vaz de Alencar ${ }^{6}$

\section{ABSTRACT}

Objective: to analyze the evidence from the scientific literature about nursing care for prevention, detection and management of delirium in elderly patients in Intensive Care Units. Method: this is an integrative review of articles published between 2013 and 2018 available in the following databases: MEDLINE, LILACS, BDENF, and CINAHL. The data were analyzed through the Content Analysis technique. The results were presented in figures. Results: six articles met the objective of the study, from which two categories emerged: 1. Prevention, identification and management of delirium by the nursing team in elderly patients admitted to Intensive Care Units; 2. Importance of educational interventions with nursing teams in Intensive Care Units. Conclusion: it was observed that the studies analyzed are incipient. It is noteworthy that non-pharmacological measures contribute to the syndrome. It is necessary to carry out continuing education with nursing teams in order to prepare them for the prevention, recognition and management of delirium in elderly patients in intensive care units. Descriptors: Nursing Care; Intensive Care Unit; Delirium; Elderly; Prevention; Health of the Elderly.

\section{RESUMO}

Objetivo: analisar as evidências da literatura científica acerca do cuidado de enfermagem na prevenção, detecção e manejo do delirium em idosos na Unidade de Terapia Intensiva. Método: trata-se de uma revisão integrativa em artigos publicados entre 2013 e 2018 nas bases MEDLINE, LILACS, BDENF e CINAHL. Analisaram-se os dados pela técnica de Análise de Conteúdo. Apresentaram-se os resultados em figuras. Resultados: encontraram-se seis artigos que atenderam ao objetivo do estudo, dos quais emergiram 2 categorias: 1. Prevenção, identificação e manejo do delirium realizado pela equipe de enfermagem à pessoa idosa na Unidade de Terapia Intensiva; 2 . Importância da realização de intervenções educativas com a equipe de enfermagem na Unidade de Terapia Intensiva. Conclusão: constatou-se que os estudos analisados são incipientes. Aponta-se que as medidas não farmacológicas contribuem no combate da síndrome. Faz-se necessária a realização de educação permanente com a equipe de enfermagem a fim de prepará-la para prevenção, reconhecimento e manejo do delirium em idosos na unidade de terapia intensiva. Descritores: Cuidados de Enfermagem; Unidade de Terapia Intensiva; Delirium; Idoso; Prevenção; Saúde do Idoso.

\section{RESUMEN}

Objetivo: analizar las evidencias de la literatura científica acerca del cuidado de enfermería en la prevención, detección y manejo del delirium en adultos mayores en la Unidad de Terapia Intensiva. Método: se trata de una revisión integradora en artículos publicados entre 2013 y 2018 realizada en las bases MEDLINE, LILACS, BDENF y CINAHL. Se analizaron datos por medio de la técnica de Análisis de Contenido. Se presentaron los resultados en figuras. Resultados: se encontraron seis artículos que atendieron al objetivo del estudio, de los cuales surgieron 2 categorías: 1. Prevención, identificación y manejo del delirium realizado por el equipo de enfermería a la persona mayor en la Unidad de Terapia Intensiva; 2. Importancia de la realización de intervenciones educativas com el equipo de enfermeira en la Unidad de Terapia Intensiva. Conclusión: se constató que los estudios analizados son incipientes. Se apunta que las medidas no farmacológicas contribuyen en el combate del síndrome. Es necesaria la realización de educación permanente con el equipo de enfermería para perpararlo para prevención, reconocimiento y manejo del delirium en adultos mayores en la unidad de terapia intensiva. Descriptores: Cuidados de Enfermería; Unidad de Terapia Intensiva; El delirio; Personas de Edad Avanzada; Prevención; Salud del Anciano.

1,2,3,4Universidade Federal da Bahia/UFBA. Salvador (BA), Brasil. ORCID (D): http://orcid.org/0000-0002-6094-7218 E-mail: laracruzj07@gmail.com ORCID (D): http://orcid.org/0000-0001-5819-0570 E-mail: tomenezes50@gmail.com ORCID (D): http://orcid.org/0000-0002-1690-4122 E-mail:

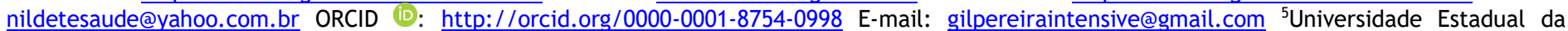
Bahia/UNEB. Salvador (BA), Brasil. E-mail: veronicaenf@hotmail.com ORCID (D): http://orcid.org/0000-0002-0671-4464 ${ }^{6}$ Universidade Estadual de Campinas/UNICAMP. Campinas (SP), Brasil. ORCID (D): http://orcid.org/0000-0001-5705-5449 E-mail: liliammvaz@gmail.com

How to cite this article

Pessoa LSC, Menezes TMO, Gomes NP, Pereira GS, Batista VM, Alencar LMV de. Nursing care for elderly patients with delirium in intensive care units. J Nurs UFPE on line. 2019;13:e239682 DOI: https://doi.org/10.5205/1981-8963.2019. $\underline{239682}$ 


\section{INTRODUCTION}

Delirium is defined as a neurobehavioral disorder manifested as a change in consciousness and cognition, which develops over a short period of time and tends to fluctuate, resulting in deficits in attention, memory, distraction, disorientation, and language impairments. ${ }^{1-2}$ Its incidence and prevalence is higher in elderly people due to the presence of frailty, congenital deficit, severity of the disease, and comorbidities. ${ }^{3-4}$ It is considered a geriatric emergency of common occurrence directly related to clinical worsening and length of hospital stay, ${ }^{5}$ as well as to increased morbidity, mortality, and rehabilitation rates after discharge, especially in the elderly. ${ }^{6-8}$

It is observed that delirium is a frequent complication in Intensive Care Units (ICUs), an environment where the continuous monitoring, stabilization and improvement of the clinical picture of hospitalized individuals are the primary goals. $9-10$ The profile of patients that predominates in ICUs is mostly composed of elderly patients, and it isobserved that nurses consider ICUs as environments that favor the development of this disorder. ${ }^{11-13}$

It is evidenced that confusion is a condition related to predisposing risk factors such as advanced age, transfer of another institution, change of environment, previous cognitive disorders, reduced mobility and chronic diseases, and to precipitant factors such as the use of anticholinergic and benzodiazepine drugs, absence of natural light, sleep deprivation, high noise level, use of physical restraint, and invasive procedures. $^{13}$

It is understood that the nursing team has a primary role in the prevention and detection of delirium because nursing is the professional category that provides direct health care and accompany patients 24 hours a day, mainly in ICUs. ${ }^{7}{ }^{14-15}$ It has been observed that the development of non-pharmacological measures is fundamental in the management and prevention of delirium. ${ }^{16-17}$ It is noted that the implementation of educational interventions with nurses in ICUs contributes to improve their knowledge and skills on the recognition of the problem and its standardized evaluation. ${ }^{18}$

It is considered that elderly patients are more likely to develop delirium when they are in an ICU, and the prevalence of this disorder is high. Thus, it is necessary to raise awareness of healthcare team regarding the use of instruments to detect the problem as early as possible, as well as the implementation of actions that may prevent its occurrence and strategies that minimize the damages caused in elderly patients admitted to ICUs.

\section{OBJECTIVE}

- To analyze the evidence from the scientific literature about nursing care for prevention, detection and management of delirium in elderly patients in Intensive Care Units.

\section{METHOD}

This is an integrative literature review. The six phases of an integrative review were considered, namely: 1) elaboration of the guiding question; 2) search or sampling in the literature; 3) data collection; 4) critical analysis of the studies included in the review; 5) discussion of results; and 6) synthesis of the review. ${ }^{19}$

Two instruments were used to gather the main information of the selected articles. The first one addressed the authors, year and country of publication, journal, and type of study. The second, addressed the article code, title, and the nursing care measures mentioned.

The guiding question was: What is the evidence from the literature about nursing care measures for prevention, detection and management of delirium in elderly patients admitted to Intensive Care Units? The databases searched were: Medical Literature Analysis and Retrieval System Online (MEDLINE), Latin American and Caribbean Health Science Literature (LILACS) and Nursing Database (BDENF) through the Virtual Health Library (VHL). The Cumulative Index to Nursing and Allied Health Literature (CINAHL) was also used. Data collection took place from 01 to 31 December, 2018.

The following Health Sciences Descriptors (DECS) were used: "Unidade de Terapia Intensiva"; "Delirium"; "Idoso"; and "Cuidados de Enfermagem" in the MEDLINE, LILACS and BDENF databases. In CINAHL and MEDLINE, the same descriptors were used in English: "Intensive Care Unit"; "Delirium"; "Aged"; and "Nursing Care". All were crossed with the Boolean operator "AND".

The established inclusion criteria were: 1. Articles available in full length and free of charge; 2. Articles published in English, Portuguese and Spanish; 3. Articles published between 2013 and 2018; 4. Articles related to nursing care in the prevention, recognition and management of delirium in elderly patients admitted to ICUs. The following cases were excluded: 1. Dissertations and literature reviews; 2 . Articles related to the theme addressing the adult population in general;

3. Duplicate articles.

We found 271 publications in the four databases surveyed. However, after filtering them according to the established criteria, six articles were selected. We used the Content Analysis technique proposed by Bardin. The following categories emerged: 1) Prevention, identification and management of delirium by the nursing team in elderly patients admitted to ICUs; and 2) 


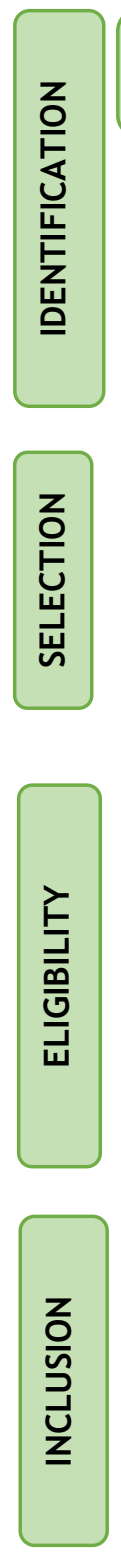

Records identified through searches in the databases $(n=123)$
Records identified through surveys in other data sources $(n=155)$



Studies included

in the qualitative synthesis $(n=3)$

Figure 1. Flowchart of organization and selection of studies. Salvador (BA), Brazil, 2018.

\section{RESULTS}

Data on authors, year and country of publication, and period and type of study are shown in Figure 2:

\begin{tabular}{|c|c|c|c|c|}
\hline Author & Year & Country & Journal & Study Type \\
\hline $\begin{array}{l}\text { Whitcomb, Morgan, Irvin, } \\
\text { Spencer,Boynton, Turman, } \\
\text { Rhodes }^{25}\end{array}$ & 2013 & $\begin{array}{l}\text { United } \\
\text { States }\end{array}$ & $\begin{array}{l}\text { Dimensions of Critical Care } \\
\text { Nursing }\end{array}$ & Qualitative \\
\hline $\begin{array}{l}\text { Faustino, Pedreira, Silva, } \\
\text { Freitas }^{21}\end{array}$ & 2016 & Brazil & $\begin{array}{ll}\text { Revista } & \text { Baiana } \\
\text { Enfermagem } & \end{array}$ & Qualitative \\
\hline $\begin{array}{l}\text { Faustino, Pedreira, Silva, } \\
\text { Freitas, Amaral } 22\end{array}$ & 2016 & Brazil & $\begin{array}{l}\text { Revista Brasileira de } \\
\text { Enfermagem }\end{array}$ & Qualitative \\
\hline $\begin{array}{l}\text { Numan, Boogaard, Kamper, } \\
\text { Rood, Peelen, Slooter }{ }^{23}\end{array}$ & 2017 & $\begin{array}{l}\text { The } \\
\text { Netherlands }\end{array}$ & $\begin{array}{l}\text { Journal of the American } \\
\text { Geriatrics Society }\end{array}$ & Quantitative \\
\hline
\end{tabular}

Figure 2. Summary of the articles selected for the study. Salvador (BA), Brazil, 2018.

Codes were created in order to identify the studies from 01 to 06 . Regarding the countries of origin of the publications, two (33\%) were published in Brazil and four (67\%) in the following countries: the United States, Thailand, Australia and the Netherlands. This showed that publications on the theme were most prevalent in foreign countries. 


\begin{tabular}{|c|c|c|}
\hline Code & Title of the article & Nursing care measures \\
\hline S01 & $\begin{array}{l}\text { A pilot study on delirium in } \\
\text { the intensive care unit: a } \\
\text { creative inquiry project with } \\
\text { undergraduater nursing } \\
\text { students. }{ }^{26}\end{array}$ & $\begin{array}{l}\text { Identification of delirium in patients through } \\
\text { the ICDSC. Need to monitor and limit } \\
\text { interactions with them at night. Use of } \\
\text { strategies to control light and noise, decreasing } \\
\text { stimuli at night. }\end{array}$ \\
\hline S02 & $\begin{array}{l}\text { Under-recognition of } \\
\text { delirium in older adults by } \\
\text { nurses in the intensive care } \\
\text { unit setting. }{ }^{7}\end{array}$ & Nurses used the CAM-ICU to assess delirium. \\
\hline S03 & $\begin{array}{l}\text { Knowledge and practices of } \\
\text { the nursing team for the } \\
\text { prevention and monitoring of } \\
\text { delirium in the elderly } 22\end{array}$ & $\begin{array}{l}\text { Actions of educational, practical, technical and } \\
\text { managerial character, involving intersectoral } \\
\text { articulation. }\end{array}$ \\
\hline S04 & $\begin{array}{l}\text { Prevention and monitoring of } \\
\text { delirium in the elderly: an } \\
\text { educational intervention. }{ }^{23}\end{array}$ & $\begin{array}{l}\text { They prevent with reorientation and promotion } \\
\text { of sleep, and control the patient's condition } \\
\text { with physical restraint and prescription drugs. }\end{array}$ \\
\hline S05 & $\begin{array}{lr}\text { Recognition of } & \text { Delirium in } \\
\text { Postoperative } & \text { Elderly } \\
\text { Patients: A } & \text { Multicenter } \\
\text { Study. }{ }^{24} & \end{array}$ & $\begin{array}{l}\text { The CAM-ICU scale was used in daily practice to } \\
\text { evaluate delirium, twice or three times a day, } \\
\text { in the ICU and general units. }\end{array}$ \\
\hline S06 & $\begin{array}{l}\text { Diagnosing delirium in very } \\
\text { elderly intensive care } \\
\text { patients. }{ }^{25}\end{array}$ & $\begin{array}{l}\text { Nurses detect and document signs of delirium } \\
\text { before the medical staff. This probably reflects } \\
\text { the longer periods of time the nurse spends on } \\
\text { the outside compared to doctors, which } \\
\text { facilitates the detection of delirium. }\end{array}$ \\
\hline
\end{tabular}

Figure 3. Title of journals and main nursing care measures identified

\section{DISCUSSION}

- Prevention, identification and management of delirium by the nursing team in elderly patients admitted to ICUs

It is known that, due to the work process of the nursing team, knowing the risk factors that elderly patients admitted to an ICU presents is fundamental in order to measure the probability of developing delirium, and to adopt preventive measures, monitor clinical signs and ensure a better prognosis. ${ }^{21}$ Early care by the nursing team is necessary to decrease the occurrence of this disorder, as well as to minimize the damage caused by it. Among the clinical manifestations that are important for the identification of the clinical picture, the nursing team mentiones the presence of psychomotor agitation, disorientation, disconnected speech, hallucinations, and sudden loss of memory. The problem is recognized when these signs are intense. However, signs of the hypoactive type such as lethargy, apathy, and reduced degree of response to stimuli were not considered. ${ }^{21-22}$

It is noteworthy that the rates of identification by nurses were higher when the patients included had more severe picture of delirium, and specialists contested the occurrence of the disorder in patients who presented the hypoactive subtype. ${ }^{23}$ It is noticed that nurses do not prioritize patients with hypoactive delirium because of their failure to recognize the condition, which is a common problem even among specialists. ${ }^{16}$ It is important to emphasize the importance of training that qualifies the team to recognize delirium since the first clinical manifestations, as well as to distinguish the subtypes manifested: mixed, hypoactive, and hyperactive.

It is observed that the detection and documentation of signs of delirium in ICUs by nurses occur more frequently before the medical team, due to the fact that they spend most of the time at the bedside. ${ }^{24}$ Tools and systems should be used in order to contribute effectively to early assessment and treatment.

It is notable that the use of the screening scale known as Confusion Assessment Method for the Intensive Care Unit (CAM-ICU) is not incorporated into the practice of nurses. ${ }^{21-22}$ The delirium index was evaluated through the application of the CAMICU by nurses and it was observed that, despite of this, the CAM-ICU is not routinely used in ICUs in Thailand, and clinical manifestation is the main strategy used for identification., ${ }^{7,23}$

The Intensive Care Delirium Screening Checklist (ICDSC) was used to assess delirium, but the study did not report whether the use was common ${ }^{25}$. The need to implement the scales became evident in the research conducted in the units, so as to incorporate new practices to identify the disorder. It is important to note that the recognition of delirium among nurses is still incipient. It is necessary to adopt strategies to better qualify these professionals regarding the importance of early identification of the problem and use of screening tools for diagnosis. ${ }^{7,22}$

A similar result was found in a survey carried out in the Netherlands, in which the daily screening for delirium by nurses was insufficient; however, in this study, only cases registered by the 
Pessoa LSC, Menezes TMO, Gomes NP, et al.

nurses in the medical records were included. ${ }^{23}$ Detecting the disorder, as well as registering this information in medical records, stand out as important actions. This is a necessary element of communication among members of the multiprofessional team, which must act together in the prevention, identification and management of delirium.

It was observed that the nursing team had difficulty recognizing the disorder in patients who used benzodiazepines. ${ }^{7}$ A careful evaluation of drugs that may precipitate the development of delirium should be performed, taking into acount that the risk of drug-induced disorder in the elderly is caused by changes in the body that result from aging. ${ }^{21}$ The use of some drugs may contribute to the triggering of delirium in any age group, but especially in the elderly, due to typical changes of senescence.

A research conducted in Thailand in 2015 was the first to deal with the under-reporting of delirium in ICUs. ${ }^{7}$ There is a need for greater attention through publications on the subject, as well as provision of training and qualification addressing the prevention, recognition and management of delirium, especially aimed at professionals working in ICUs.

It was verified that the approach by means of non-pharmacological measures helps in the management and prevention of delirium among hospitalized elderly patients. ${ }^{21-22,25}$ It is known that interrupting the sleep of hospitalized elderly at night increases the chances of developing delirium; for this reason, it is necessary that nurses limit nocturnal care activities and be capable of identifying this disorder. ${ }^{25}$ Other studies corroborated that sleep deprivation is one of the factors that precipitate delirium and that nurses prevent it when they promote adequate sleep and rest in hospitalized elderly. ${ }^{21-22}$

It is understood that reducing the light and noise of the multi-parameter monitor contributes to good sleep. It should be emphasized that, as non-pharmacological measures, the health team should pay attention to orientation in time and space, procedures and devices in use, as well as perform early mobilization, allow the use of prosthetics, glasses and hearing aids. ${ }^{21-22,25}$ The implementation of these measures is considered important to prevent the problem at the admission of the elderly into the unit.

The importance of the presence of family members as partners in the care, preventing and reducing the damages caused by delirium is emphasized. Visiting hours should be increased and actions such as exposure to familiar objects should be adopted to stimulate memory and thus decrease isolation. ${ }^{21}$ It is understood that it is fundamental to raise awareness among health teams and encourage the presence of the patients'
Nursing care for elderly patients with delirium...

families in order to avoid the occurrence of the syndrome and minimize the chances of a worse prognosis.

Importance of educational interventions with nursing teams in ICUs

It is noteworthy that in two studies conducted in an ICU in Brazil, educational interventions were carried out with the nursing team, through pedagogical workshops. ${ }^{21-22}$ The actions carried out contributed to the development of critical awareness about delirium, increase of knowledge, and improved nursing practices, among them, the reduction of excess noise, flexibilization of the use hearing aids, eyeglasses and dental prostheses, and use of more clocks in the unit, by updating the knowledge about the disorder. ${ }^{22}$ It was found that only a third of the detected problems were solved; the others were only minimized. The provision of new restraints, sleep eye masks, and earplugs had to be submitted to bidding processes and the resolution could be delayed. ${ }^{22}$ It is worth noting that the costs of acquiring these objects are lower when compared to the costs of prolonged hospitalization caused by delirium. Therefore, it is necessary that managers of hospitals to acknowledge this problem.

It was evidenced that the updating of the topic of training nurses in intensive care units increased the recognition rate among professionals and suggested that the strategy should be kept, as well as the routine evaluation of patients with potential for confusional conditions, with the aid of validated tools and non-pharmacological measures for prevention and management of delirium. ${ }^{3,14}$

It was found during workshops conducted in a study that the knowledge of the team about delirium was superficial, although practices of reorientation in time and space and sleep promotion were performed to prevent the disorder. ${ }^{21}$ It was noticed that the low number of studies about the realization of educational interventions points out the need for more such actions in order to train the teams and reduce the incidence of delirium in ICUs.

It is emphasized that, problematizing the reality in this units favors the elaboration of new methods to coordinate the work process and, thus, reorganize the care practices through dialogue, according to the lived reality. ${ }^{22}$ Continuing education with nurses is effective in improving the knowledge about delirium, but it is necessary that such initiatives happen continuously and that professionals incorporate learning into their practices, because without sustained effort, the progress is transitory. ${ }^{26} \mathrm{~A}$ research in Australia corroborated that nurses are ideal professionals to identify the problem and carry out continuing education. ${ }^{24}$ 
Pessoa LSC, Menezes TMO, Gomes NP, et al.

There is a need to clarify to the nursing team the real effects of the use of drugs to reduce hyperactive delirium. ${ }^{21}$ This can be done through courses, training and educational activities aimed at motivating the professionals to participate and gain knowledge, with the goal of minimizing the rates of occurrence of the problem.

It is understood that this work reinforces the importance of nursing care in the prevention, recognition and monitoring of delirium, improving the quality of care and reducing the consequences of the syndrome in elderly patients hospitalized in ICUs.

As a limitation of the study, the reduced number of publications on this topic must be mentioned. It is suggested that the subject be approached since undergraduate courses, to favor the early knowledge of future professionals, in order to minimize the occurrence of delirium.

\section{CONCLUSION}

It is concluded that the data found in this review about nursing care for prevention and management of delirium in elderly patients admitted to ICUs are still incipient, considering that the vast majority of studies were excluded because they addressed nursing care measures to patients with delirium in the general adult population.

It is evidenced that the nursing team identifies more easily the hyperactive subtype through clinical evaluation, not using the validated scales for delirium. Non-pharmacological measures contribute to the fight against the disorder, and the implementation of educational interventions assists in the quality of care for elderly people experiencing delirium.

In this sense, it is expected that this study come to contribute to the sensitization of nursing teams through continuing education strategies, in order to prepare them for prevention, recognition and management of delirium in elderly patients admitted to ICUs, mainly through nonpharmacological practices.

\section{REFERENCES}

1. American Psychiatric Association. Manual Diagnóstico e Estatístico de Transtornos Mentais. Porto Alegre (Brasil): Artmed; 2014.

2. Fabbri RMA. Delirium. In: Freitas EV; Ligia PY. Tratado de Geriatria e Gerontologia. 4. ed. Rio de Janeiro. Grupo Editorial Nacional; 2016.

3. Tostes I, Pereira S, Almeida L, Santos M. Delirium em terapia intensiva: utilização do Confusion Assessment Method for the Intensive Care Unit pelo enfermeiro. Rev Fund Care Online. 2018 Jan/Mar;10(1):2-8. Doi: http://dx.doi.org/10.9789/21755361.2018.v10i1.2-8
Nursing care for elderly patients with delirium...

4. Mori S, Takeda JRT, Carrara FSA, Cohrs CR, Zanei SSV, Whitaker IY. Incidence and factors related to delirium in an intensive care unit. Rev EsC Enferm USP. 2016 May;50(4):587-93. Doi: http://dx.doi.org/10.1590/S0080-

\section{4}

5. Mehta S, Cook D, Devlin JW, Skrobik Y, Meade $M$, Fergusson $D$, et al. Prevalence, risk factors, and outcomes of delirium in mechanically ventilated adults. Crit Care Med. 2015 May;43(3):557-66.

10.1097/CCM.0000000000000727

6. Klouwenberg PMK, Zaa IJ, Spitoni C, Ong DSY, Kooi AWVD, Bonten MJM et al. The attributable mortality of delirium in critically ill patients: Prospective cohort study. The BMJ. 2014 May;349:1-10. Doi: 10.1136 / bmj.g6652

7. Panitchote A, Tangvoraphonkchai K, Suebsoh N, Eamma W, Chanthonglarng B, Tiamkao S, et al. Under-recognition of delirium in older adults by nurses in the intensive care unit setting. Aging Clin Exp Res. 2015 Dec;27(5):735-40. Doi: 10.1007 / s40520-015-0323-6

8. Almeida ACF, Pedroso JL. Delirium na UTI. In: Knobel E. Condutas no paciente grave. 4th ed. São Paulo. Atheneu, 2016.

9. Luna A, Entringer P, Silva L. Prevalência do subdiagnóstico de delirium entre pacientes internados em unidade de terapia intensiva. Rev Enferm UERJ. 2016 June;24(1);e6238. Doi: http://dx.doi.org/10.12957/reuerj.2016.6238

10. Salah MS, Gaeedy GE. Intensive Care Unit Admission and Outcomes in Gaza. Ann Public Health Res [Internet]. 2018 [cited 2018 June 15];5(1):1069. Available from: https: / / www.jscimedcentral.com/PublicHealth/p ublichealth-5-1069.pdf

11. Pauletti M, Otaviano MLP, Moraes AST, Schneider DS. Perfil epidemiológico dos pacientes internados em um Centro de Terapia Intensiva. Aletheia [Internet]. Jan/Dec 2017 [cited 2018 May 23];50(1-2)38-46. Available from: http://www.periodicos.ulbra.br/index.php/alethe ia/article/view/4160/2987

12. Prece A, Cervantes J, Mazur CS, Visentin A. Perfil de pacientes em terapia intensiva: necessidade do conhecimento para organização do cuidado. Cad. da Esc. de Saúde [Internet]. 2016 may [cited 2018 May 1];2(16):35-48. Available from:

http://portaldeperiodicos.unibrasil.com.br/index. php/cadernossaude/article/view/2462/2032

13. Capone NA, Dalfior JL. Delirium: Fatores de Risco. In: Flôres G, Capone NA, editores. Delirium no Paciente Grave. São Paulo: Atheneu, 2013.

14. Lin WL, Chen YF, Wang J. Factors associated with the development of delirium in elderly patients in Intensive Care Units. J Nurs Res. 2015 
May;23(4):322-9.

Doi:

10.1097/JNR.0000000000000082

15. Faustino TN. Prevenção e monitorização do delirium no idoso crítico [dissertação de mestrado]. Salvador: Universidade Federal da Bahia. Curso de Enfermagem, Escola de Enfermagem, 2015.

16. Karabulut N, Aktaş YY. Nursing Management of Delirium in the Postanesthesia Care Unit and Intensive Care Unit. J Perianesth Nurs. 2016 June; 31(5):397-405. Doi: 10.1016 / j.jopan.2014.10.006

17. Rivosecchi RM, Kane-Gill SL, Svec S, Campbell $\mathrm{S}$, Smithburger PL. The implementation of a nonpharmacologic protocol to prevent intensive care delirium. J Crit Care. 2016 Dec;31(1):206-11. Doi: 10.1016 / j.jcrc.2015.09.031

18. Ribeiro S, Nascimento E, Delacanal D, Jung, Bertoncello, Cilene. Conhecimento de enfermeiros sobre o delirium em pacientes críticos: discurso do sujeito coletivo. Texto contexto - enferm. 2015 June;24(2):513-

520. Doi: http://dx.doi.org/10.1590/0104-

\section{4.}

19. Souza MT, Silva MD, Carvalho R. Integrative review: what is it? How to do it? Einstein [Internet]. 2010 may [cited 2018 May 1];8(1 Pt 1):102-6.

Available from:

http://www.scielo.br/pdf/eins/v8n1/pt_16794508-eins-8-1-0102.pdf

20. Bardin, L. Análise de conteúdo. Lisboa, Portugal: Edições 70, 2016.

21. Faustino TN, Pedreira LC, Freitas YS, Oliveira RM. Conhecimentos e práticas da equipe de enfermagem para prevenção e monitorização do delirium em idosos. Rev Baiana Enferm. 2016 Dec;30(3):1-10.

Doi:

http://dx.doi.org/10.18471/rbe.v30i3.15794

22. Faustino T, Pedreira L, Freitas Y, Silva R, Amaral J. Prevenção e monitorização do delirium no idoso: uma intervenção educativa. Rev Bras Enferm. 2016 Dec;69(4):725-32. Doi: http://dx.doi.org/10.1590/0034-7167.2016690416i

23. Numan $T$, Van den Boogaard H, Kamper AM, Rood PJT, Peelen LM, Slooter AJC et al. Recognition of Delirium in Postoperative Elderly Patients: A Multicenter Study. J Am Geriatr Soc. 2018 dez; 65(9)1932-38. Doi: 10.1111 / jgs.14933

24. Heriot NR, Levinson MR, Mills AC, Khine TT, Gellie AL, Sritharan G. Diagnosing delirium in very elderly intensive care patients. Intensive Crit Care Nurs. 2017 Dec;38:10-17. Doi: 10.1016/j.iccn.2016.07.002

25. Whitcomb JJ, Morgan M, Irvin T, Spencer K, Boynton L, Turman S. A pilot study on delirium in the intensive care unit: a creative inquiry project with undergraduate nursing students. Dimens Crit Care Nurs. 2013 Dec; 32(5):266-70. Doi: 10.1097 / DCC.0b013e3182a077cd
26. Hickin SL, White S, Knopp-Sihota J. Nurses' knowledge and perception of delirium screening and assessment in the intensive care unit: Longterm effectiveness of an education-based knowledge translation intervention. Intensive Crit Care Nurs. 2017 Dec;41:43-9. Doi: 10.1016/j.iccn.2017.03.010

Submission: 2019/02/04

Accepted: 2019/03/25

Publishing: 2019/06/13

Corresponding Address

Larissa Simões da Cruz Pessoa

E-mail: laracruzj07@gmail.com 